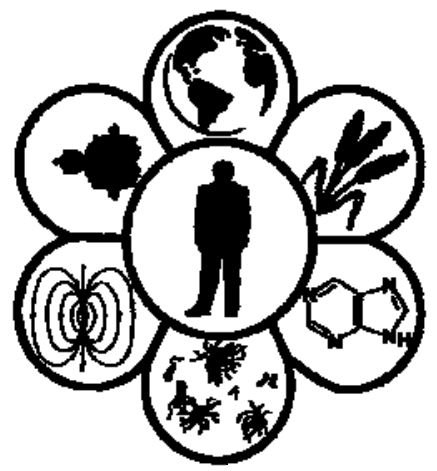

Вісник Дніпропетровського університету. Біологія, медицина Vìsnik Dnìpropetrovs'kogo unìversitetu. Serìa Bìologîa, medicina

Visnyk of Dnipropetrovsk University. Biology, medicine

Vìsn. Dnìpropetr. Unìv. Ser. Bìol. Med. 2014. 5(1), 45-48.

doi:10.15421/021409

ISSN 2310-4155 print

ISSN 2312-7295 online

www.medicine.dp.ua

УДК 579.88

\title{
Частота виявлення мікоплазм урогенітального тракту жінок у м. Дніпропетровськ
}

\author{
К.В. Бубало ${ }^{1,2}$, Л.П. Голодок ${ }^{1}$, А.І. Вінніков ${ }^{1}$ \\ ${ }^{1}$ Дніпропетровський національний університет імені Олеся Гончара, Дніпропетровськ, Україна \\ ${ }^{2}$ Діагностичний центр Дніпропетровської медичної академї̈, Дніпропетровськ, Украӥна
}

\begin{abstract}
Досліджено частоту виявлення урогенітальних мікоплазм у жінок різного віку культуральним методом тест-система DUO 3 метою встановлення їх етіологічного значення у розвитку запальних процесів урогенітального тракту жінок. Ідентифіковано досліджувані культури Mycoplasma hominis, Ureaplasma urealyticum у діагностичному титрі $>10^{4}$ КУО/мл і у титрі $<10^{3}$ КУО/мл. Із 120 досліджуваних ізолятів урогенітального тракту жінок виявлено 113 штамів генітальних мікоплазм, із них 63\% - Ureaplasma urealyticum, 32\% - Mycoplasma hominis, 3\% - мікробна асоціація Ureaplasma urealyticum - Mycoplasma hominis. Домінантним збудником запальних процесів урогенітального тракту жінок вікової категорії 24-29 років є Ureaplasma urealyticum. За відсутності ознак запального процесу U. urealyticum зустрічається у низькій концентрації удвічі частіше, ніж у діагностично значимій концентрації. Збільшення кількості колонієтвірних одиниць міко- та уреаплазм слугує маркером розвитку запального процесу урогенітального тракту жінок. Культуральний метод тест-система DUO дозволяє дати чутливішу кількісну характеристику мікоплазм, а ПЛР - виявити збудник у дуже низькій концентрації. Для ефективної лабораторної діагностики необхідно застосовувати комплексні методи для підвищення вірогідності виявлення збудника та верифікації діагнозу урогенітальної інфекції.
\end{abstract}

Ключові слова: тест-система DUO; ПЛР; Ureaplasma urealyticum; Mycoplasma hominis; урогенітальний тракт

\section{Frequency of urogenital mycoplasma detection in women of Dnipropetrovsk}

\author{
K.V. Bubalo ${ }^{1,2}$, L.P. Golodok ${ }^{1}$, A.I. Vinnikov ${ }^{1}$ \\ ${ }^{1}$ Oles Honchar Dnipropetrovsk National University, Dnipropetrovsk, Ukraine \\ ${ }^{2}$ Diagnostic Center of Dnipropetrovsk Medical Academy, Dnipropetrovsk, Ukraine
}

\begin{abstract}
The frequency of urogenital mycoplasmas detection in women of different ages was studied in culture with the help of DUO test-system in order to determine their etiological significance in the development of inflammatory processes of women urogenital tract. We identified the researched cultures Mycoplasma hominis, Ureaplasma urealyticum in the diagnostic titer $>10^{4} \mathrm{TEM} / \mathrm{ml}$ indicating severe contamination by microorganisms, and in the titer $<10^{3} \mathrm{TEM} / \mathrm{ml}$, the carrier state of the identified microorganisms. Of 120 studied isolates of women urogenital tract there have been identified 113 strains of genital mycoplasmas, among which $63 \%-U$. urealyticum, $32 \%-$ M. hominis, 3\%microbial association of $U$. urealyticum - M. hominis. According to the study of frequency of detection of urogenital mycoplasma using DUO test-system culture method, it was found that the most frequently observed ones were U. urealyticum in 75 women (63\%) of all individuals, M. hominis in 38 women (32\%) in different diagnostic titers $\left(>10^{4} \mathrm{TEM} / \mathrm{ml},<10^{3} \mathrm{TEM} / \mathrm{ml}\right)$ in 4 women (3\%) U. urealyticum $M$. hominis was observed in microbial associations and mycoplasma were not found in 3 women $(2 \%)$ of all surveyed patients. U. urealyticum and M. hominis in the diagnostic titer of $>10^{4} \mathrm{TEM} / \mathrm{ml}$ was observed in 55 women (46\%) and 20 women (17\%), respectively, and the titer of $<10^{3} \mathrm{CFU} / \mathrm{ml}$ U. urealyticum was observed in 20 women (17\%), and M. hominis in 18 women (15\%). Analysis of genital mycoplasmas distribution among women of different ages has shown that there was the certain correlation between the patient age and frequency of genital mycoplasmas detection: the highest detection rate was observed in women age of 24-29. The dominant pathogen of urogenital tract inflammatory processes in women in 24-29 age group is $U$. urealyticum. The comparison of DUO test-system and PCR data has shown that DUO test-system in culture allowed more sensitive quantitave characterization of mycoplasmas, however, for the more effective laboratory diagnostics it was necessary to use complex methods to increase the probability of pathogen detection. Incidence of mycoplasmas in women with the presence of inflammation was higher than in women having the inflammation in the genital tract. In this case, potential symptom-
\end{abstract}

Дніпропетровський національний університет імені Олеся Гончара, пр. Гагаріна, 72, Дніпропетровськ, 49010, Україна.

Oles Honchar Dnipropetrovsk National University, pr. Gagarina, 72, Dnipropetrovsk, 49010, Ukraine.

Tel.: +38-067-790-70-92. E-mail:a_vinnikov@ukr.net 
free carriers exist for the development of inflammation of urogenital tract of women. Scientists have proved that mycoplasma could cause vulvovaginitis, urethritis, paraurethritis, bartholinitis, adnexitis, salpingitis, endometritis, and ovaritis.

Keywords: DUO test-system; PCR; Ureaplasma urealyticum; Mycoplasma hominis; urogenital tract

\section{Вступ}

Мікоплазмові урогенітальні інфекції посідають одне 3 провідних місць серед інших інфекцій людини, що передаються статевим шляхом (Rivera, 2001; TaylorRobinson, 2012; LeRoy, 2012). При цьому показники відповідної захворюваності у різних регіонах світу досить варіабельні, коливаються в межах 10-80\% усієї інфекційної урогенітальної патології. Поширеність мікоплазмової урогенітальної інфекції складає 3,931,0\% у Мексиці, (Rivera, 2004), 44,8\% - у Китаї (Zuo, 2006), 54,9\% - у Туреччині (Karabay, 2006). В Україні нині немає статистично достовірних даних про поширеність урогенітального мікоплазмозу у різних груп населення. Аналіз показників поширеності генітальних мікоплазм в Україні має ряд труднощів через відсутність достатньо надійних i достовірних епідеміологічних досліджень. Отримані в останні десятиліття дані вітчизняних і зарубіжних дослідників класифікують захворювання урогенітального тракту, асоційовані 3 мікоплазмовою інфекцією, як один із проявів дисбалансу біоти в цілому.

Результати досліджень різних учених досить суперечиві. Деякі дослідники вважають мікоплазми умовно-патогенними мікроорганізмами, обгрунтовуючи це можливістю виділення їх від клінічно здорових, а також осіб із безсимптомним клінічним перебігом мікоплазмозу (Lypova, 2004; Petrikkos, 2007; Pereyre, 2009). Разом із цим, на думку інших авторів, мікоплазми $€$ патогенними агентами, а виділення їх від клінічно здорових осіб слід розглядати як загрозливе носійство, 3 огляду на подовжену дію персистувального збудника, а також можливість підвищення вірулентності штамів мікоплазм (Bashmakova, 2006). Незважаючи на неоднозначність думок відносно патогенної ролі Mycoplasma hominis i Ureaplasma urealyticum, ВООЗ розглядає їх як можливих етіологічних агентів при гонококовому уретриті, запальних захворюваннях органів малого таза та бактеріальному вагінозі. При цьому як моноінфекція мікоплазмоз спостерігається лише в 12-18\% випадків, а в асоціації 3 іншими патогенними мікроорганізмами (мікст-інфекція) у $87-90 \%$, із хламідіями - в 25-30\% випадків (Boesen, 2004; Ross, 2005).

За сучасними уявленнями M. hominis, U. urealyticum, $U$. parvum є умовно-патогенними мікроорганізмами, які можуть виявитися в урогенітальному тракті практично здорових жінок. Але носійство мікоплазм не заперечує їх етіологічну роль, оскільки подібне носійство спостерігається в умовах багатьох інфекцій. Як і у випадку інших безсимптомних інфекцій, при мікоплазмозах мікроорганізми можуть активізуватися під дією різних екзогенних і ендогенних факторів (Zdrodowska-Stefanow et al., 2006). Зростання інтересу до цієї групи інфекцій сприяло детальнішому вивченню клінічно-патогенетичних особливостей дії мікоплазм, зокрема їх впливу на репродуктивну, менструальну, ста- теву функції жіночого організму, що визначає високу соціальну значимість даної проблеми.

На основі багатьох проведених досліджень розроблено різні методи діагностики жінок із мікоплазмовою інфекцією: бактеріологічний, молекулярний (ПЛР), біохімічний (тест-система DUO) і серологічний. За останні роки у лабораторній діагностиці відбулися помітні позитивні зміни, які дозволяють значною мірою оптимізувати клінічно-лабораторні обстеження пацієнтів, контролювати ефективність терапії. Разом із цим проблема повноцінного обстеження та лікування хворих залишається цілком актуальною, свідченням цього $є$ невдачі терапії, хронізація процесу (Deguchi, 2004). Враховуючи все наведене вище, вивчення мікоплазмової інфекції дуже актуальне у наш час, оскільки нині спостерігається значне поширення цієї інфекції в популяції (10-50\% - M. hominis, 11-80\% - U. urealyticum), при цьому iї оцінка як епідеміологами, так i клініцистами (Jensen, 2012) недостатня.

Мета роботи - визначити частоту виявлення мікоплазм і уреаплазм серед жінок різного віку, провести оцінку біоценозу урогенітального тракту жінок із безсимптомним носійством уреа- та мікоплазмової інфекції за допомогою різноманітних методів.

\section{Матеріал і методи досліджень}

Посів біологічного матеріалу на живильні середовища, дослідження та інтерпретацію отриманих результатів проводили загальноприйнятими методами (Medinform, 2003). Ідентифікували виділені мікроорганізми бактеріоскопічними, бактеріологічними, біохімічними методами.

На першому етапі дослідження здійснили взяття та висів біологічного матеріалу. У пацієнтів для бактеріологічного аналізу відбирали такі його зразки: відокремлюване уретри та цервікального каналу. Матеріал за допомогою спеціального стерильного зонда вносили у рідке транспортне живильне середовище, яке містить усі необхідні речовини для зберігання уреаплазм і мікоплазм, інгібуючи ріст сторонньої мікрофлори за рахунок наявності у середовищі антибіотиків і антимікотиків. Потім із транспортного живильного середовища здійснювали пересів матеріалу на сухі комерційні диференційно-діагностичні середовища, які, крім основних поживних речовин для росту мікоплазм (холестерину та нуклеїнових кислот), містять $0,1 \%$ аргініну для виділення $M$. hominis, $0,1 \%$ сечовини - для U. urealyticum, а також індикатор фенолового червоного у концентрації $0,002 \%$, зміна кольору якого свідчить про розклад аргініну або сечовини 3 утворення аміаку. Посіви інкубували в термостаті 24-48 годин для уреаплазм і 4872 години для мікоплазм за температури $+37^{\circ} \mathrm{C}$. Жовточервоний колір середовища переходить у ліловий у результаті ферментативної активності за рахунок росту мікоплазм. Цей метод дозволяє візуально визначити наявність мікоплазм у досліджуваному матеріалі. 
На другому етапі дослідження проводили кількісну оцінку чисельності U. urealyticum i M. hominis культуральним методом за допомогою тест-системи DUO (Sanofi - Франція), яка дозволяє визначити титр обох мікроорганізмів у досліджуваному матеріалі. Мікропіпеткою переносили клінічний матеріал на кожну лунку плашки. Плашки з клінічним матеріалом культивували протягом 24 годин за температури $+37^{\circ} \mathrm{C}$. Після інкубації проводили оцінку результатів. Позитивні результати дослідження враховували при діагностично значимому титрі $>10^{4}$ КУО/мл. Також проводили виявлення генетичного матеріалу у досліджуваних зразках за допомогою методу ПЛР. Генотипування культур, накопичених у рідкому живильному середовищі, проводили за допомогою тест-системи Літех (Москва). Синтез ДНК здійснювали на ампліфікаторі Терцик (ДНК-технологія, Росія). Кількість ДНК мікроорганізмів у зразку прийнято виражати в геном-еквівалентах (ГЕ).

У мікробіологічному відділі Діагностичного центру Дніпропетровської медичної академії досліджено зразки біологічного матеріалу 120 жінок різного віку.

\section{Результати та їх обговорення}

На першому етапі вивчали загальну картину біоценозу урогенітального тракту жінок. Виділено 113 штамів генітальних мікоплазм, із них 75 - U. urealyticum, 38 - M. hominis. Згідно 3 дослідженням частоти виявлення урогенітальних мікоплазм культуральним методом за допомогою тест-системи DUO виявили, що найчастіше спостерігалась $U$. urealyticum, найменше M. hominis у різних діагностичних титрах $\left(>10^{4}\right.$, $<10^{3}$ КУО/мл), у незначній кількості виявлялися U. urealyticum - M. hominis у мікробній асоціації - чотири досліджених зразка, зовсім не виявилися мікоплазми у трьох зразках з усіх досліджених ізолятів урогенітального тракту обстежених пацієнток (табл. 1).

Таблиия 1

Кількість досліджених зразків паціснток із діагностичним титром M. hominis i $\boldsymbol{U}$. urealyticum

\begin{tabular}{|c|c|c|}
\hline $\begin{array}{c}\text { Діагностичний титр } \\
\text { мікроорганізмів }\end{array}$ & $\begin{array}{c}\text { M. hominis, \% } \\
(n=38)\end{array}$ & $\begin{array}{c}\text { U. urealyticum, \% } \\
(n=75)\end{array}$ \\
\hline$>10^{4}$ КУО/мл & 17 & 46 \\
\hline$<10^{3}$ КУО/мл & 15 & 17 \\
\hline Усього & 32 & 63 \\
\hline
\end{tabular}

Дослідження частоти виявлення мікоплазм методом полімеразної ланцюгової реакції (ПЛР) показало наявність генетичного матеріалу $U$. urealyticum у 65 зразках (54\%) досліджуваного матеріалу, при цьому 38 зразків $(32 \%)$ відповідали значенню $U$. urealyticum у титрі $>10^{4}$ КУО/мл і 27 зразків (22\%) відповідали кількості U. urealyticum у матеріалі $<10^{3}$ під час визначення культуральним методом за допомогою тест-системи DUO, у 10 зразках генетичного матеріалу не виявлено. Генетичний матеріал M. hominis виявлено у 38 зразках (32\%), при цьому 20 зразків (17\%) відповідали значенню M. hominis у титрі $>10^{4}$ КУО/мл і 18 (15\%) відповідали кількості штамів M. hominis у титрі $<10^{3} \mathrm{KУО/мл.}$

Серед усіх зразків, які мали позитивні результати, отримані методом ПЛР, тільки 38 зразків (32\%) містили $U$. urealyticum у титрі $>10^{4}$ КУО/мл і 20 зразків (17\%) M. hominis у концентрації $>10^{4} \mathrm{KУО/мЛ,} \mathrm{які} \mathrm{мають}$ клінічне значення. Менші концентрації цих мікроорганізмів не мають клінічного значення, хоча $\mathrm{i}$ виявляються ПЛР як позитивні. Імовірність отримання помилково позитивних результатів за використання ПЛР суттєво вища, ніж за тестування в наборі «Мікоплазма DUO». Це пов'язано 3 можливим неспецифічним зв'язуванням ДНК уреа- та мікоплазми як мішені, а також із можливою контамінацією зразків продуктами реакції.

На другому етапі дослідження 3 метою вивчення розповсюдження мікоплазмової інфекції у жінок різних вікових категорій пацієнток поділили на вікові групи. До I групи увійшли 78 пацієнток: виявлення мікоплазмової та уреаплазовної урогенітальної інфекції, клінічні прояви запальних процесів у сечостатевих органах, відсутність вагітності. До II групи увійшли 39 пацієнток, у яких не виявлялося ознак запального процесу генітального тракту (безсимптомне носійство).

Частота виявлення генітальних мікоплазм у групі жінок із проявами запального процесу урогенітального тракту: у дівчат 12-17 років - 3\%, у віковій групі 18-23$15 \%$, у жінок віком 24-29 - 32\%, у віковій групі 30 35 років - 14\%, у жінок понад 36 років - 3\%. У жінок без прояву запального процесу частота виявлення мікоплазм менша, ніж у I групі обстежених пацієнток: у дівчат 1217 років - 1\%, у віковій групі 18-23 - 3\%, у жінок віком $24-29-15 \%$, у віковій групі 30-35 - 11\%, у жінок понад 36 років $-3 \%$ (табл. 2 ).

Частота поширення (\%) генітальних мікоплазм у жінок різних вікових груп

Таблиия 2

\begin{tabular}{|l|c|c|c|c|c|c|}
\hline \multirow{2}{*}{ Вік, років } & \multicolumn{3}{|c|}{ I група $(n=78)$} & \multicolumn{3}{c|}{ II група $(n=39)$} \\
\cline { 2 - 7 } & U. urealyticum & M. hominis & $\begin{array}{c}\text { M. hominis - } \\
\text { U. urealyticum }\end{array}$ & U. urealyticum & M. hominis & $\begin{array}{c}\text { M. hominis - } \\
\text { U. urealyticum }\end{array}$ \\
\hline $12-17$ & 2 & 1 & 0 & 0 & 1 & 0 \\
\hline $18-23$ & 9 & 5 & 1 & 2 & 1 & 0 \\
\hline $24-29$ & 21 & 8 & 3 & 9 & 6 & 0 \\
\hline $30-35$ & 10 & 4 & 0 & 6 & 5 & 0 \\
\hline Старші 36 & 0 & 2 & 1 & 1 & 2 & 0 \\
\hline Усього & 42 & 20 & 5 & 17 & 10 & 0 \\
\hline
\end{tabular}

Порівняльна оцінка даних, отриманих у результаті лабораторного дослідження, показала, що найчастіше генітальні мікоплазми зустрічаються у жінок віком 24
29 років. При цьому значно частіше виявляються U. urealyticum, ніж M. hominis, яка являє собою мікроорганізм із вищим патогенним потенціалом, ніж 
M. hominis. За відсутності ознак запального процесу U. urealyticum зустрічається у низькій концентрації удвічі частіше, ніж у діагностично значимій концентрації. Збільшення кількості колонієтвірних одиниць міко- та уреаплазм може слугувати маркером розвитку запального процесу урогенітального тракту жінок. Найчастіше поширення генітальних мікоплазм у жінок віком 24-29 років пов'язане з підвищеною сексуальною та репродуктивною активністю, інколи воно може бути пов'язане 3 наявністю герпесвірусної інфекції та кандидомікозу.

Найменша частота виявлення спостерігається у дітей і поодинокі випадки - у жінок віком понад 36 років. Отримані дані свідчать про зв'язок U. urealyticum iз клінічними проявами запальних процесів урогенітального тракту і збігаються з результатами інших авторів. Ряд авторів (Robertson, 2002; Aujard, 2005; Jensen, 2013) довели, що мікоплазми можуть бути причиною вульвовагініту, уретриту, парауретриту, бартолініту, андекситу, сальпінгіту, ендометриту, запалення яєчників. Безсимптомне носійство урогенітальних мікоплазм слід розглядати як стан ризику розвитку інфекційного процесу внаслідок дії факторів різної природи: змішані інфекції, зміна гормонального та імунного статусу організму тощо. Персистенція урогенітальних мікоплазм в організмі жінки може супроводжуватися прихованими паталогічними змінами, пов'язаними 3 дисбіозом піхви. У вигляді моноінфекції мікоплазмова інфекція була присутня лише у 20 пацієнтів (17\%), в усіх інших випадках (83\%) мікоплазмова інфекція виявлялася у поєднанні 3 іншими етіологічно значимими мікроорганізмами у вигляді мікст-інфекції.

\section{Висновки}

Iз виділень урогенітального тракту жінок ідентифіковано генітальні мікоплазми U. urealyticum у $63 \%$ (75 зразків) і M. hominis - у 32\% випадків (38 зразків). Аналіз розповсюдження мікроорганізмів у жінок різного віку показав, що домінантним збудником уреаплазмової інфекції у жінок $є \quad U$. urealyticum. Найпоширеніша уреаплазмова інфекція у жінок віком 24-29 років, що пов'язано 3 високою статевою активністю. У вигляді моноінфекції мікоплазмова інфекція присутня лише у 20 пацієнток (17\%), в інших випадках (83\%) мікоплазмова інфекція виявлялася у поєднанні 3 іншими етіологічно значимими мікроорганізмами у вигляді мікст-інфекції.

Порівнюючи різні методи дослідження (молекулярні методи ПЛР і культуральний метод тест-систему DUO), встановили, що для ефективнішої лабораторної діагностики мікоплазмової інфекції необхідно застосовувати комплексну діагностику для підвищення вірогідності виявлення збудника у досліджуваних зразках.

\section{Бібліографічні посилання}

Aujard, Y., Maury, L., Doit, C., 2005. Ureaplasma urealyticum and Mycoplasma hominis infections in newborns: Personal data and review of the literature. Arch. Pediatr. 12(1), 12-18.
Bashmakova, M.A., 2006. Laboratory diagnosis of genital infections. Reproduct. Problem. 5(1), 25-28 (in Russian).

Boesen, T., Emmersen, J., Baczynska, A., 2004. The vaa locus of Mycoplasma hominis contains a divergent genetic islet encoding a putative membrane protein. BMC Microbiol. 4(1), 37-38.

Deguchi, T., Yoshida, T., Miyazawa, T., 2004. Association of Ureaplasma urealyticum (biovar 2) with nongonococcal urethritis. Sex. Transm. Dis. 31(3), 192-195.

Jensen, A., Kleveland, C., Moghaddam, A., 2013. Chlamydia trachomatis, Mycoplasma genitalium and Ureaplasma urealyticum among students in northern Norway. J. Eur. Acad. Dermatol. Venereol. 27(1), 146-147.

Karabay, O., Topcuoglu, A., Kocoglu, E., 2006. Prevalence and antibiotic susceptibility of genital Mycoplasma hominis and Ureaplasma urealyticum in a university hospital in Turkey. Clin. Exp. Obstet. Gynecol. 33(1), 36-38.

LeRoy, C., LeHen, I., Clerc M., Arfel, K., 2012. The first performance report for the Bio-Rad Dx CT/NG/MG assay for simultaneous detection of Chlamydia trachomatis, Neisseria gonorrhoeae and Mycoplasma genitalium in urogenital samples. J. Microbiol. Methods. 89(3), 193-197.

Lypova, E.V., Batakaev, E.V., 2009. Urogenital systems of associated infection with Mycoplasmas. Clin. Dermatol. Venereol. 26, 455-460.

Pereyre, S., Sirand-Pugnet, P., Beven, L., 2009. Life on arginine for Mycoplasma hominis: Clues from its minimal genome and comparison with other human urogenital mycoplasmas. Plos. Genet. 10(5), 367-368.

Petrikkos, G.L., Hadjisoteriou, M., Daikos, G.L., 2007. PCR versus culture in the detection of vaginal Ureaplasma urealyticum and Mycoplasma hominis. Int. J. Gynaecol. Obstet. 97(3), 202-203.

Rivera, J.A., Centeno, M., Santellan, O.M., Rodríguez, N.M., 2004. Prevalencia de Ureaplasma urealyticum en mujeres. Rev. Mex. Patol. Clin. 51(1), 33-36 (in Spanish).

Rivera, J.A., Cedillo, M.L., Vega, M., 2001. Micoplasmasy su importancia médica. Rev. Biomed. 12(4), 262-271 (in Spanish).

Robertson, J.A., Stemke, G.W., Davis, J.W., 2002. Proposal of Ureaplasma parvum sp. nov. and emended description of Ureaplasma urealyticum. Int. J. Syst. Evol. Microbiol. 52(2), 587-597.

Ross, J.D., 2005. Is Mycoplasma genitalium a cause of pelvic inflammatory disease? Infect. Dis. Clin. North. Am. 19(2), 407-408.

Taylor-Robinson, D., 2007. The role of mycoplasmam in pregnancy outcome. Best. Pract. Res. Clin. Obstet. Gynaecol. 21(3), 425-438.

Taylor-Robinson, D., Jensen, J.S., Svenstrup, H., Stacey, C.M., 2012. Difficulties experienced in defining the microbial cause of pelvic inflammatory disease. Int. J. STD AIDS 23(1), 18-24.

Zdrodowska-Stefanow, B., Kosowska, W.M., OstaszewskaPuchalska, I., 2006. Ureaplasma urealyticum and Mycoplasma hominis infection in women with urogenital diseases. Adv. Med. Scien. 51(1), 250-253.

Zuo, C.X, Huang, J.H., Chen, J., Lu, J.Y., Xiang, Y.P., 2006. [Female urogenital mycoplasma infection and drug sensitivity status in Changsha]. Nan. Fang. Yi. Ke. Da. Xue. Xue. Bao. 26(6), 831-836 (in Chinese).

Надійшла до редколегї 11.04.2014 